\title{
MADONNA, A PARRÊSIA, O SIMULACRO
}

\author{
MADONNA, THE PARRÊSIA, THE SIMULACRUM
}

\author{
Atílio Butturi Junior \\ Universidade Federal da Fronteira Sul \\ Universidade Federal de Santa Catarina - PPGLg
}

\begin{abstract}
Resumo
Este trabalho pretende, a partir de uma perspectiva arqueogenealógica, discutir as relações possíveis entre o discurso da cantora Madonna e o conceito de parrêsia. Para tanto, recorre inicialmente aos apontamentos de Michel Foucault acerca das modalidades de subjetivação via verdade, surgidas e desenvolvidas segundo as problemáticas do cuidado de si e da parrêsia. Adiante, elenca características da chamada parrêsia cínica e traça paralelos entre esta e três enunciados de Madonna: o livro Sex e duas entrevistas contemporâneas deste. Finalmente, discute a mesma aproximação segundo a diferenciação realizada por Jean Baudrillard entre sedução e gozo, percebendo no discurso de Madonna um complicador parresiástico, qual seja, o simulacro da indústria do entretenimento.
\end{abstract}

Palavras-chave: Madonna. Parrêsia. Cuidado de si. Filosofia cínica.

\begin{abstract}
This paper aims, from the perspective of an archaeogenealogy, discuss possible relationships between the discourse of Madonna and the concept of parrêsia. It is based initially on appointments of Michel Foucault on the modalities of subjectivity by truth emerged and developed along the issues of self-care and parrêsia. Below, lists characteristics of the call cynical parrêsia and draws parallels between this and three statements of Madonna, the book Sex and two contemporary interviews this. Finally, it discusses the same approach according to the differentiation made by Jean Baudrillard between seduction and pleasure, concluding in the Madonna's speech Madonna not parrêsia but the simulacrum of the entertainment industry.
\end{abstract}

Keywords: Madonna. Parrêsia. Self-care. Cynical philosophy.

\section{INTRODUÇÃO}

Cena um: duas cabeças raspadas em que se lê "Love" e "Fame”. Não se sabe ao certo se há diferença de gêneros, mas uma outra figura, nada ambivalente, pontua o centro da tomada. Trata-se de Lady Gaga, espécie de grau zero do gozo, simulacro de mulher e, adiante, de transexual - Gaga há poucos dias assumiu seu "hermafroditismo" sem dar detalhes. A personagem ostenta longa cabeleira platinada, trajes sumários, e intenta uma performance supostamente sexual. Adiante, desfilam toda sorte de fantasias, milimétricas em sua transparência: Gaga no meio de uma gangue, Gaga aos beijos com mulheres e homens, Gaga se debatendo com policiais, Gaga simulando masturbação... A música, espécie de pano de fundo irrelevante, acena: “Eu posso te ver lá nos blocos 
me olhando/ Com um sorriso em sua boca e sua mão no p.../ Nossa história tem sempre o mesmo começo/ Um menino e uma menina e um [...] e um jogo”.

Cena dois: adolescente observa, lânguida, o horizonte do alto de um edifício em ruínas. Decididamente, a mocinha desce ao centro do universo e vai se deparando com a variedade estimulante dos corpos e suas possibilidades de gozo. Ao que parece, um calor demasiado obriga a personagem em questão, e todas as demais que imediatamente desfilam nas tomadas, a uma exasperação de suores e a um abandono progressivo - e compulsivo - da indumentária. A figura, novamente, é absoluta na ânsia de tudo dizer: Britney Spears, naquilo que seria sua evolução necessária de adolescente provocativa à musa adulta do desejo. Entre gemidos e suspiros, ouve-se uma letra imponente: "Eu sou uma escrava para você/ Eu sei que sou meio jovem/ Mas também tenho sentimentos também/ E preciso fazer o que tenho vontade/ Então deixe-me ir”.

Cena três: dominatrix surge entre uma cortina dourada. Unhas pontiagudas, um gesto de convite a participar de um mundo. Nova tomada: duas personagens explicitamente se desfazem do que vestem, enquanto um quadro na parede - é numa biblioteca que se desenrola a cena - indica a espreita de um olhar taciturno e atemporal. Novo corte: surgem o título, "Erotica", e um rosto bastante conhecido porque multiplicado ao espectral - a cantora Madonna. A seguir, somos lançados a uma impudica festa em que uma figura feminina é voyeur ignorada entre mancebos devidamente submissos. Novo corte: Madonna e a atriz Isabela Rossellini (quase-musa do sadomasoquismo fílmico) numa praia, beijando-se e aliciando outras garotas, um tanto assustadas. Corte. E outro. E mais. Sussurros corroboram o indômito do gozo: "Se eu te pegar por trás/ Me enfiar em sua mente/ Quando você menos esperar/ Você vai tentar rejeitar/ Se eu estiver no comando e tratá-lo como criança/ Você vai ficar louco?/ Deixar minha boca ir até onde ela deseja?”.

Respectivamente, estamos em 2009, 2001, 1992. Três videoclipes: Love game, I'm a slave for you e Erotica. Nos três casos, a obstinação pela transparência radical do desejo. No entanto, uma diferença a se marcar: uma empresa de ruptura e acontecimento no discurso de Madonna, que inaugura a transgressão subjetiva como ferramenta axial do discurso musical. Em outros termos: o discurso de Madonna, a partir dos finais da década de oitenta e início da década de noventa, assevera uma tentativa de obliterar aquilo que diz respeito apenas à música e trazer à tona não o determinante artístico, mas questões relacionadas à verdade do sujeito que, como porta-voz de certos grupos específicos, tem como atribuição principal desmistificar e retraçar configurações de poder-saber e verdade.

Madonna funcionaria como elemento de cisão com uma indústria cultural baseada numa repetição massificada de cânones artísticos, já que não apenas teria transcendido o limiar dos mass media, mas, de modo radical, teria subvertido a ordem de importância entre o conteúdo estético (político-estético) e o sujeito que o produz. Nessa esteira, caberia atualmente se questionar acerca da verdade dos sujeitos que desfilam num mundo de celebridades e afins e não apenas inventariar e resenhar os produtos de uma suposta estética de massificação.

Tal estratégia de deslocamento de foco é sobejamente reconhecida: das agruras lisérgicas de artistas como Amy Winehouse aos dramas familiares-sexuais de Britney 
Spears, a viragem constitutiva de Madonna concerne à modificação na própria indústria: multiplicação das falas de si, proliferação de discursos e comentários constitutivos de mitos cada vez mais efêmeros e implosão do modelo de artista profissional, pautado na excelência dos desempenhos especificamente estéticos. Não é à toa que toda cantora que se paute numa vida escandalosamente pública - como Spears e Gaga - é alçada ao posto de "nova Madonna" pela imprensa - especializada ou não. Nesse caso, é emblemática a posição de Gaga no que se refere à assunção de uma espécie de vida verdadeira": "É o maior erro achar que Lady Gaga é um personagem ou algo assim. [...] Eu sou 150 mil por cento Lady Gaga todos os dias” (GAGA, 2009, p.68).

Se, então, ainda permanece na discussão acerca do universo pop uma certa nostalgia do artístico, suplantado pelo regime da celebração da vida pessoal dos parvenus dos mass media, o fundamental, porém, seria perscrutar esse acontecimento na modalidade específica pela qual esses sujeitos, instados pelo regime de dizer que Madonna circunscreveria, cometem o discurso verdadeiro: como se apoderam de um dizer de si mesmos estrategicamente, no intuito de dirigir seus ouvintes-telespectadores, de governar os demais de acordo com a fundação de uma estética de existência, de um cuidado de si, de uma insistência no deslindar da vida verdadeira.

Isso posto - e em termos foucauldianos - a proposta deste texto é discutir qual seria a possibilidade de reler Madonna conforme a epiméleia heaoutoû e a parrêsia ${ }^{2}$, dando ênfase ao momento denominado parrêsia cínica, marcado pelo escândalo via "inversão da moeda”, relativa aos padrões morais estabelecidos. Ademais, será preciso apontar nessa modalidade do dizer sobre si uma dificuldade relativa à "diferença ética", sobretudo porque o lugar de que fala a cantora - e, por conseguintes, aqueles que compartilham seu solo arqueogenealógico - é não o da preocupação com a identidade entre quem diz e o que diz, mas o da derrisão desse entendimento causada pela própria instância enunciativa, a saber, o vértice entre a constituição da subjetividade e a simulação demandada sempre-já pela indústria do entretenimento.

Nesse esforço - e baseado numa perspectiva arqueogenealógica de análise de discurso , este texto se divide em três seções: Cuidado de si e parrêsia, traçando um percurso da manutenção e modificação dos conceitos; Cinismo e parrêsia, detalhando a modificação instaurada pela filosofia cínica no modo de ser da parrêsia; Entre parrêsia e simulacro, em que se faz uma análise breve dos enunciados de Madonna e se discute os limites do parresiástico em seu discurso.

\section{CUIDADO DE SI E PARRÊSIA}

Na década de oitenta, nos meandros do retorno do sujeito e da história à pauta dos principais intelectuais franceses, Michel Foucault retoma sua empresa de discussão sobre o saber-poder e a constituição dos sujeitos seguindo a ordem de uma reviravolta: a aparição da subjetividade numa espécie de dobra - e instância de transformação - de todo regime do dizer. Segundo Deleuze (2005 ${ }^{3}$, p.111, grifo meu), haveria no

\footnotetext{
${ }^{1}$ Voltarei ao tema da vida verdadeira conforme analisado por Foucault (2009).

${ }^{2}$ Utilizo aqui, respectivamente, as grafias da tradução de Foucault (2006) e do texto de Foucault (2009).

${ }^{3}$ O original é de 1986.
} 
pensamento foucauldiano - desse chamado “último Foucault", não obstante a multiplicação dos dispositivos, o vislumbre de uma relação de resistência elaborada na subjetivação:

O que é preciso colocar, então, é que a subjetivação, a relação consigo, não deixa de se fazer, mas se metamorfoseando, mudando de modo, a ponto do modo grego tornar-se uma lembrança bem longínqua. Recuperada pelas relações de poder, pelas relações de saber, a relação consigo não pára de renascer, em outros lugares e em outras formas.

A problemática da subjetivação foucauldiana, iniciada na discussão da História da sexualidade via regime dos aphrodisia e da discussão da enkrateia, ganha destaque na produção posterior, inicialmente, com a elaboração de uma cisão entre a epiméleia heautoû, o cuidado de si, e o gnôthi seautón, o "conhece-te a ti mesmo" - o que, para o filósofo, permitia generalizar sobremaneira o nó entre sujeito e verdade.

As histórias desses dois conceitos fundantes da filosofia ocidental são descritas por Foucault: o cuidado de si e o conhece-te a ti mesmo estariam atrelados, mas, o que é a novidade da inversão foucauldiana, epiméleia heautoû seria o quadro mais geral do debate sobre a verdade e o sujeito, de que gnôthi seautón seria uma modalidade. É já na tradição socrática - via Platão - que esse cuidado se si surge, em textos como a Apologia e o Alcebíades (FOUCAULT, 2006), passando pelo epicurismo e pelo cinismo, até desembocar na tradição cristã na forma da vida ascética. Ainda que a noção tenha se reconfigurado discursivamente, três de suas características são descritas:

[...] A epiméleia heautoû é uma atitude - para consigo, para com os outros, para com o mundo.

[...] O cuidado de si implica uma certa maneira de estar atento ao que se pensa e ao que se passa no pensamento. [...]

Em terceiro lugar, a noção de epiméleia não designa simplesmente esta atitude geral ou esta forma de atenção voltada pra si. Também designa sempre algumas ações, ações que são exercidas de si pra consigo, ações pelas quais nos assumimos, nos modificamos nos purificamos, nos transformamos e nos transfiguramos. [...] (FOUCAULT, 2006, p.14-15)

Para o francês, o ponto nodal é inquirir acerca da separação entre a verdade do sujeito e a história dos regimes de veridicção, ou seja, o momento em que o sujeito e a verdade são apartados, cujo marco seria o "momento cartesiano" e a evidência do sujeito e do seu acesso direto ao ser. O século XVII, herdeiro das racionalizações cristãs acerca da existência de Deus e do regime cartesiano, teria sido o responsável por expulsar o cuidado de si como questão relevante, cindindo o pensamento entre a espiritualidade que questiona os limites do conhecimento sob a égide da problematização da subjetividade - e o conhecimento, típico do mundo moderno, cuja formalização e a exterioridade não concernem “à estrutura do sujeito como tal” (FOUCAULT, 2006, p. 23).

É a separação entre o dizer verdadeiro e a subjetivação que discute esse Foucault: a expulsão de uma ética do filosofar e do pensar, já que é perfeitamente possível, a partir 
de Descartes, ter acesso à verdade sem qualquer preocupação ético-moral. Segundo Adorno (2004, p.58), a diferença entre espiritualidade fundada nos gregos e conhecimento organizado na ideia cartesiana "se deve ao fato de que, para os gregos, a legitimidade e a validade de uma opinião não se manifestam no respeito a um critério inerente aos próprios procedimentos de enunciação”.

Não obstante o sucesso desta expulsão, o retorno da problemática da epiméleia teria se dado já em Kant e tomado forma vigorosa desde o século XIX: o cuidado de si estaria vinculado à tradição de questionamento dos limites de todo cognoscível e, ainda mais importante, na relação estabelecida entre o alcance da verdade e a transformação do sujeito. É justamente essa modalidade, a espiritual, mantida como senda positiva de modificação do próprio papel do filósofo, que Foucault faz convergir com o discurso da parrêsia: falar francamente inaugura a necessidade de se voltar a si mesmo e se interrogar na medida do comprometimento com o que se enuncia e do risco que tal exige.

No curso ministrado no Collège de France em 1984, Foucault (2009) vai retornar à cisão elaborada precedentemente, corroborando-a, de início, com a distinção entre formas epistemológicas e formas aletúrgicas de relação com o dizer verdadeiro: enquanto as primeiras dizem respeito à estruturação formal do dizer verdadeiro, as formas aletúrgicas de produção de verdade dizem respeito à constituição do sujeito que as diz. A questão seria, pois: "à partir de quelles pratiques discursives a-t-on essayé de dire la verité sur le sujet?” (FOUCAULT, 2009, p.5).

Foucault em seguida estabelece que o objetivo é discutir a forma historicizada de se questionar acerca do estatuto dos dizeres. Isso posto, se há duas tradições que remontam à Antiguidade - conhecimento e espiritualidade -, o que pretende o arqueólogo é indagar o modo do verdadeiro que engaja o sujeito numa ética, num cuidado de si e num risco: a parrêsia. Nem um espelhamento direto entre sujeito e objeto (da ordem do gnôthi seauton), nem uma tentativa de persuasão que prescinda da diferenciação entre verdadeiro e falso (da ordem da bajulação retórica), a relação entre sujeito e verdade na parrêsia guarda três especificidades:

Em somme, por qu'il y ait parrêsia, dans l'act de verité, il y ait: premièrement, manifestation d'um lien fondamental entre la vérité dite e la pensée de celui qui l'a dite; [deuxièment], mise em question du lien entre lês deux interlocuteurs (celui qui dit la vérité et celui auquel cette vérité est adressée). D’où ce nouveau trait de la parrêsia: elle implique une certaine forme de courage,[...] (FOUCAULT, 2009, p. 13)

No entanto, parrêsia é apenas uma das quatro modalidades utilizadas, segundo Foucault, para descrever o discurso verdadeiro, quais sejam: a primeira, o dizerverdadeiro do profeta, caracterizado não pela palavra do sujeito mas pelo papel deste como ferramenta, como mediador da voz dos deuses; a segunda, o dizer-verdadeiro do sábio, cuja estrutura é a do silêncio e da desobrigação ética, justamente porque se trata apenas de descrição neutralizante do mundo; a terceira, o dizer-verdadeiro do professor, encarregado da tekhnê, do saber-fazer com o mundo, implicado numa ausência de risco 
calcada no poder da tradição: ensinar é mesmo repetir e religar os discursos numa ordenação.

A quarta modalidade do dizer-verdadeiro, a do parresiasta, embora comprometida com cada uma das três outras de forma irremediável - os modos são funcionais e se entrecruzam constantemente -, é sempre lida sob o signo da transgressão da ordem ligada à ação da dobra subjetiva: o jogo da verdade e da alteridade que, ao inteligir o mundo, acaba por (re)construir as formas de subjetivação.

Assim é que o genealogista vai percorrer três momentos decisivos na formação e no deslocamento do conceito de parrêsia. O primeiro momento seria o da parrêsia política e diz respeito, a princípio, às qualidades intrínsecas que o cidadão, no regime democrático, por direito de herança e linhagem, possui de dizer o verdadeiro e conduzir a si mesmo e à cidade. No entanto, é desse modelo que nasce a discussão sobre o limite da democracia, calcada numa distinção problemática entre a massa e os considerados "melhores”. Da perspectiva de uma dissolução ${ }^{4}$, a escansão ética dos escolhidos entra em crise. Escreve Foucault (2009, p. 54): "La démocracie n’est pas le lieu privilegie de la parrêsia, c'est le lieu au contraire dans lequel [l'exercise de] la parrêsia est le plus dificile”.

Se, pois, a democracia é por excelência um paradoxo, visto que não há solução possível entre a massa parresiástica de um lado, e a afronta de uma oligarquia e seus privilégios, abre-se uma dualidade para o pensamento ocidental que procura mediar ética, política, verdade e subjetivação. Tal dualidade é assim exposta por Gros (2004, p.160):

De um lado, a solução platônica, que consiste em tornar de novo possível o dizer verdadeiro, mas no quadro estrito e limitado de uma educação da alma dos governantes, cuidadosamente escolhidos e triados. Por outro lado, a solução aristotélica, pela qual se salva a democracia desimpedindo-a de pressupostos éticos, mantendo apenas a alternância formal nas relações de governantes e governados.

Foucault (2006) já apontara, no entanto, o vínculo entre o aristotelismo e certa neutralidade moderna. Assim, caberia ao discurso socrático estabelecer uma nova configuração da parrêsia em detrimento daquela instaurada na democracia. É Sócrates quem inaugura a segunda modalidade, a parrêsia ética ou filosófica: "Sócrates parresiasta es no solo quien habla francamente sino quien puede desprenderse de lãs solicitaciones de los otros, del médio, para com-formarse como quien puede dar uma resposta em términos de creación de si.” (SANTOS, 2003, p.57).

Os apontamentos foucauldianos sobre o socratismo estão voltados sobretudo a dois textos: o Alcebíades e o Laques, ambos pautados na relação entre a parrêsia e a epiméleia heautoû. No primeiro, Foucault (2009) considera que o cuidado de si está intrincado com a alma, forjando a vertente da filosofia que atende pelo nome de ontologia. No Alcebíades, cuidar de si exige uma preocupação com psukhê, a alma. No segundo, o discurso socrático inauguraria uma estética da existência, calcada na ideia de bios como forma de existência que demanda um exercício, como uma estetização. Nos termos do texto, é essa a cisão que permaneceria nos recônditos da filosofia ocidental:

\footnotetext{
${ }^{4}$ Os textos em questão datam da crise da democracia que aflige Atenas no século IV a. C.
} 
Dans um cas, on a donc um mode de redition de compte de soi-même qui va à la psukhê et qui, em allant à la psukhê, désigne le lieu d'um discours métaphysique possible. Dans l'autre cas, on a une reddition de compte de soi-même, un 'rendre raison de soi-même' que se dirige vers le bios comme existence, [un] mode d'existence q'uil s'agit d'examiner et d'éprouver tout au long de cette existence-même. Porquoi? Por pouvoir lui donner, grâce à un certain discours vrais, une certe forme. [...] (FOUCAULT, 2009, p. 148)

A "certa forma" que levanta o texto é o mote de dois discursos que se interceptam: o da vida verdadeira - "vraie vie" - e o da estética da existência. A arte de existir de maneira bela será aquela que, ancorada no dizer verdadeiro, modifica e transfigura o sujeito no modo de uma marca: ou bem a ascese estóica, ou sua retomada cristã, ou as exigências de retidão do cinismo, trata-se então de um olhar exigente sobre si mesmo, de uma postura imanente e marcada no corpo que ascende à verdade - do interior e do exterior.

\section{CINISMO E PARRÊSIA}

Nesse percurso de diferenciação, a filosofia da praça pública defendida pelos cínicos ganha ares de paradigma: a exigência de uma forma de vida tipificada na forma de uma prática determinada de si exige uma harmonia entre aquele que fala a verdade e o modo com que este vive. A cisão é importante: segundo Foucault (2009, p. 159), é no bios que se dá a aleturgia cínica e, por conseguinte, na manifestação em transparência:

Il fait enfin de la forme de l'existence une façon de rendre visible, dans les gestes, dans les corps, dans la manière de s'habiller, dans la manière de se conduire et de vivre, la vérité elle-même. En somme, le cynisme fait de la vie, de l'existence, du bios, ce qu'on pourrait appeler aune alèthurgie, une manifestation de la vérité.

Para Foucault, a viragem primeira dos cínicos é, antes de mais nada, a de uma postura pública que transcenderia os limites temporais. Assim, haveria uma repetição de certas características desse dizer verdadeiro da bios, evocada pelo ascetismo cristão, pelos militantes revolucionários, ou pelo papel revolucionário e de carnavalização exercido pela arte. Acerca da relevância da postura cínica anacrônica no discurso da arte, Foucault faz lembrar da constituição da "vida do artista”, na Renascença, cuja herança será refletida nos modernismos dos séculos XIX e XX: primeiramente, porque a arte romperia com a vida "normal" que permitiria o acesso a uma "outra vida"; depois, a vida verdadeira do artista garantiria a autenticidade do artefato estético, sob a égide do escândalo - a quebra constante do discurso normal perpetrada pelos cínicos (FOUCAULT, 2009).

Ademais, Foucault (2009) faz notar uma "tradição cínica" existente no mundo ocidental, um “modelo cínico” de existência, cujo cerne estaria na configuração de uma segunda via para a existência ordinária. No entanto, em oposição ao modelo da outra vida transcendental, circunscrito pelo poder do logos e exigindo um outro mundo, a modalidade cínica seria a da prática de si, a via da askesis, do dobrar-se sobre si 
segundo a bios. Portanto, não revolução operada para um além, mas operação heróica de sublevação na imanência.

Não é possível, porém, se enganar com o heroísmo cínico: não se trata de uma vida modelar baseada na sabedoria e tão cara à Antiguidade grega. O herói cínico é artífice da sublevação via corpo e carregaria no bojo, conforme Foucault (2009), uma cisão do próprio pensamento filosófico ocidental, qual seja, de um lado, a tradição de ensinamento e doutrinação via sabedoria; de outro, em disputa e aproximação com aquela, uma filosofia do heroísmo e uma preocupação subjetivante nos empreendimentos cognoscíveis:

On peut à partir de là concevoir l'idée d'une histoire de la philosophuie qui pourrait être um peu autre que celle qu'on enseigne traditionellement de nous jours, une histoire de la philosophie qui ne serait pas une histoire des doctrines philosophiques, mais [des] formes, modes et styles de vie, une histoire de la vie philosophie comme problème philosophique, mais aussi comme mode d'être et comme forme à la fois d'étique et d'héroïsme (FOUCAULT, 2009, p.195-196)

Para tanto, a modalidade da epiméleia heaoutoû desenvolvida pela via da vida verdadeira cínica, pela estetização da existência num exercício diário e intermitente, é a vida escandalosa. Se o cinismo é uma filosofia do bios e da praça pública - seu caráter é do popular e do oral -, é nessa circunscrição espacializada que se travará a militância revolucionária: mostrar a vida, expor seus detalhes mais rudimentares e privados, sua miséria e sua necessidade de problematização se dará, na parrêsia cínica, como condição sine qua non do dizer verdadeiro.

Nesse caso, o aspecto geral do cuidado de si dos cínicos é esclarecedor: doutrina da pauperidade, aproximação do bestial, publicidade do sexual. Foucault (2009) inventaria quatro aspectos fundantes da estetização parresiástica cínica: a vida não dissimulada, a vida independente, a vida reta e a vida soberana. Os quatro, não obstante, têm seu regime instado - dir-se-ia pré-figurado - por um princípio geral, pedra de toque responsável pela cesura do cinismo com a filosofia tradicional: o parakaharattein to nomisma, cuja tradução evoca uma historieta grega e diz respeito a uma inversão de valores, a uma “alteração da moeda” (FOUCAULT, 2009).

Ao que concerne essa expressão? A um entendimento do nomisma seguindo a ordem do nomos, a cultura na língua grega. Segundo Foucault, então, parakaharattein nomisma corresponderia a uma ascese e um exercício de si, a uma epiméleia e um acesso ao verdadeiro pautada na inversão dos costumes gerais, numa desordem militante: a vida verdadeira cínica é parresiástica mas sob a égide da transvaloração dos valores:

Le príncipe d'altérer le nomisma, c'est aussi celui de changer la coutume, rompre avec elle, briser les règles, les habitudes, les conventions et les lois. Il est três vraisemblable que, quel qu'ait été le sens originaire de cette formule, c'est bien ainsi qu'elle était recue et comprise. (FOUCAULT, 2009, p.224) 
A parrêsia cínica, pois, só pode ser pensada na forma de uma coragem escandalosa diante dos costumes da cidade. Não, certamente, o mesmo de coragem da qual dependia a própria vida, porque dita essencialmente aos poderosos e aos governantes por excelência ética, mas a da coragem do desnudamento, do grau zero do pudor, do tudo mostrar para tudo dizer. Parrêsia, que Foucault (2009) aponta como a teatralização do existir em vista de uma militância transformadora da estrutura estabelecida, do nomos. Para Foucault, a soberania cínica, a independência e a retidão só são pensáveis num lugar-outro que não o da tradição, o que formularia o conceito ainda vivo de militância filosófica, de atitude de problematização do que existe: “C'est donc une militance qui prétend changer le monde [...]” (FOUCAULT, 2009, p.262).

É perseguindo a modalidade do escândalo cínico como acesso à parrêsia que empreendo, então, uma discussão acerca do discurso militante - pretensamente - da cantora Madonna.

\section{ENTRE PARRÊSIA E SIMULACRO}

A figura público-privada de Madonna é recorrente no universo da cultura ocidental desde os mass media até teses e dissertações acadêmicas (TARABORRELLI, 2003) - a partir do início da década de oitenta. Espécie de ponto de estofo das muitas mudanças que alteraram a cena musical "pop” surgida nos países de língua inglesa e que se espalhou pelo mundo a partir do fenômeno adolescente dos Beatles, a novidade constitutiva do discurso de Madonna parte do pressuposto da superexposição causada pelo surgimento da MTV para, então, reconfigurar o modo de existência do “artista”. Adiante: Madonna é a cisão necessária entre um universo musical distinto do imagético, no qual os artistas eram protegidos e seus escândalos devidamente editados ${ }^{5}$, e uma outra discursividade em que o próprio e a confluência entre publicidade radical, transparência subjetiva e assunção da inversão da moral/ética promovem justamente nessa estetização da existência.

Retomemos as "cenas” da introdução: a operação de Gaga/Spears não pode ser subsumida do discurso musical ou do videoclipe. $\mathrm{O}$ discurso aqui parte da funcionalidades midiática e deixa ver a alteridade antes proibida, o desejo e sua aparição absoluta e completamente ordenada, o gozo dissecado em seus contornos - e é sempre bom recordar Foucault e o sexo rei como o dispositivo e nada além dele (uma das teses da História da Sexualidade). É, pois, uma experiência relacionada a um desejo supostamente transgressor que, no entanto, causa apatia, porque sem força. É, ainda, uma experiência de falar de si, não somente via clipes e músicas, mas sobretudo na corporalidade, na existência como bios de sujeitos especialmente provocativos: Spears/Gaga e seus pares transnacionais estampam e constituem a tradição contemporânea da celebridade, essa instância que remete à execração do conteúdo artístico em nome da monumentalização da constituição de si.

\footnotetext{
${ }^{5}$ David Bowie pode ser um exemplo da configuração que precede Madonna: dúbio em relação à identidade, sobretudo a de gênero, seu nome nunca foi mote de debates públicos acerca de orientação sexual. O mesmo pode se dizer de Nico - a mulher-travesti (BAUDRILLARD, 1991) ou de Lou Reed. Entenda-se: o privado, as relações de desejo e a corporeidade desses artistas jamais suplantaram o viés estético. Como no discurso da sabedoria, o risco é calculado no interior do campo e a na tentativa de alterar o campo.
} 
Volto à posição cesuralista e a defendo: o discurso de Madonna teria inaugurado esse modelo pós-estético na cultura pop. Isso certamente não significa dizer que não havia um culto a celebridades, que mitos hollywoodianos ou assuntos afins nunca foram assuntos de tablóides. Significa fazer notar que Madonna promove uma viragem na relação balanceada entre vida pessoal e profissional, segundo a ordem de uma vida verdadeira como acesso a um outro mundo - no que ela vai, como tentarei mostrar, se aproximar da parrêsia cínica.

Não obstante, como discussão acerca da ordem e do estabelecido, a modalidade do dizer verdadeiro de Madonna é sempre-já comprometida em sua veridicção, pois se tratará sempre de dois movimentos: tudo dizer e tudo mostrar de sua vida segundo a ordem do desejo produtivo e do gozo, o que a inclui basilarmente no dispositivo sexual; tudo dizer e tudo mostrar na modalidade do simulacro, já que o escândalo aqui se prestará, amiúde, a uma relação contratual e não-ética.

Passo aos recortes desse discurso.

\subsection{Madonna, essa garota}

Prescindo da visão biográfica - que nasceu em 1958 e é filha de italianos, que cursou dança e venceu em Nova Iorque - e esquematizo três momentos da constituição do discurso de Madonna como vida verdadeira.

Recorte um: entre 1983 e 1987. Madonna lança os quatro primeiros discos e se torna fenômeno de vendas e de mídia. Duas questões pontuam esse primeiro instante: primeiramente, Madonna disputava a atenção do público e da crítica com Cyndi Lauper. Em 1985, Madonna saíra de um retumbante sucesso com Like a Virgen, enquanto Lauper tornava-se ícone via She' So Unusual. A imprensa especializada decretaria: a Madonna e sua vulgaridade explosiva restariam os sonhados quinze minutos de fama e o ostracismo, enquanto Lauper surgia como a forma da autenticidade pop. O problema de Madonna seria: sua imagem pública, sexualizada e provocativa transcendera o limite da música, ou seja, o caso era de uma estetização desesperada de si e não de uma empresa do campo musical (ANDERSEN, 1991).

Nesse mesmo intervalo, particularmente em 1985, novamente teremos o escândalo privado em detrimento da música: as revistas Penthouse e Playboy publicam fotos de Madonna nua em sua juventude, posando para artistas desconhecidos de Nova Iorque. Além disso, uma película de pornô-soft, protagonizada por Madonna, vem à tona. No meio do turbilhão, em entrevista, a cantora responde: "Não me envergonho de nada" (ANDERSEN, 1991, p. 164).

Recorte dois: entre 1988 a 1991. Madonna protagoniza o maior escândalo - até aquele momento - de sua carreira: em 1989, lança música via comercial da Pepsi e imediatamente um vídeo que gera controvérsia: Like a prayer, em que Madonna "beija e seduz" um santo negro. Mais do que o vídeo, é importante destacar o tom confessional instaurado no discurso. O álbum Like a prayer subverte os parâmetros adolescentes do discurso sexualizante anterior e os desloca para o falar de si, para a intimidade do sujeito e sua relação com a verdade. Pode-se ouvir desde a discussão sobre seu 
casamento mal-sucedido e a violência doméstica, até seu relacionamento conflituoso com o pai, passando pela ausência prematura da mãe (TARABORRELLI, 2003).

No entanto, a sexualidade cada vez mais se torna exasperante: em 1990, Madonna abre uma turnê - a Blond Ambition - em que o mote é a transparência do prazer e que foi registrada na forma de diário íntimo, vindo a público em 1991: o filme $\mathrm{Na}$ cama com Madonna, no qual se misturam, devidamente hiperrealizados, trechos da turnê e momentos íntimos escandalosos ${ }^{6}$, como a cena em que a cantora simula masturbação com uma garrafa de água mineral (ANDERSEN, 1991).

Madonna torna mais organizado seu discurso acerca da sexualidade. Se até aquele momento havia uma espécie de dissolução em formas variadas, que iam desde os apelos para o sexo seguro à discussão de tabus americanos como gravidez na adolescência e gênero, a guinada agora é rumo a uma politização do corpo, o que aproxima Madonna cada vez mais dos discursos de gênero como o dos same-sex-oriented ${ }^{7}$. É em 1991 que Madonna dará uma explosiva entrevista à The Advocate, afirmando sua bissexualidade e, logo em seguida, lançando sua versão estetizada do mundo das "fantasias proibidas" do desejo: o clipe de Justify my Love, proibido pela MTV americana (TARABORRELLI, 2003).

Ocorre que a transformação se dá também nos modos públicos de Madonna: é preciso ser radicalmente conforme, é preciso que haja uma vida verdadeira que sustente o discurso imagético-musical de Madonna e dê crédito à sua militância. Então, o material dos tablóides estará recheado dos escândalos da filha mais discutida (TARABORRELLI, 2003) da América: Madonna traveste seu namorado, Madonna fica semi-nua em festas e promove orgias, Madonna aparece de mãos dadas com mulheres, Madonna frequenta a noite gay.

É interessante observar, porém, que a chegada desse discurso sexual-militante é contemporânea do combate à pornografia nos Estados Unidos, principalmente ao movimento de higienização do centro de Nova Iorque. Estamos ainda sob a égide do republicanismo e a moralidade pretende varrer o caráter prolixo da diferença. Nesse caso, temos uma estratégia definida: transcender a música e se tornar heroína corresponde a ocupar um novo campo e problematizar o escopo de atuação de uma celebridade.

Recorte três: 1992. Madonna lança um disco, Erotica, um livro, Sex, um filme, Corpo em evidência. A tríade discorre sobre desejo, sexo e prazer, centrando-se na relação entre esse prazer e a violência. Transgressora-mor do universo pop de então, Madonna vocifera suas opiniões supostamente revolucionárias em todas as mídias (TARABORRELLI, 2003). Detalho esse momento como sua tentativa parresiástica.

\footnotetext{
${ }^{6}$ Circunscrevo esse escândalo ao público-alvo de Madonna: os norte-americanos.

${ }^{7}$ Não pretendo discutir aqui o discurso dos gêneros e apenas utilizo termos como same-sex-oriented ou gay por entendê-los menos carregados de valorações patologizantes e negativas.
} 


\subsection{Madonna, essa cínica}

Entrevista de Madonna à revista Veja, na época do lançamento de Sex. Sobre os supostos motivos de sua censura pública - o livro ficava "escondido", o clipe fora proibido (novamente) e a imprensa estava implacável - a cantora responde:

$1^{8}$ Eu sou censurada porque prefiro mostrar a verdade e a verdade incomoda. A ideia de me conformar não me passa pela cabeça. Faço o que eu quero e vou continuar a fazer. Os artistas não devem se conformar. Quer saber de uma coisa? Essa questão nem me preocupa. [...] Pelo contrário, não vou parar minha luta.

O entrevistador (Elio Gapari) questiona qual seria essa luta. Madonna:

2 Contra o racismo, o sexismo, a perseguição contra homossexuais, o preconceito, a ignorância.

Mais à frente, questionada pela obscenidade do seu discurso, ela é direta:

3 Existe e está diante das nossas caras. É o racismo, a discriminação sexual, o ódio, a ignorância, a miséria. Há coisa mais obscena que a guerra?

Finalmente, ao responder sobre os problemas sociais e éticos nos Estados Unidos, ela ataca, aduzindo os motivos pelos quais os EUA "vão mal”:

4 Porque nela não se diz a verdade e porque as pessoas não se divertem, não vivem a vida com prazer. É um problema que começa na infância e vai adiante no processo educacional. As pessoas são educadas para terem medo de tudo. Há medo demais por aí. ${ }^{9}$

Vejamos: Sex fora lançado em 1992 com um sucesso e uma polêmica imediatos. Tratava-se de um livro que trazia o itinerário de Madonna por toda sorte de situações sexuais, que passavam por homoerotismo e homossexualidade, travestismo, sadomasoquismo, fetichismo e tudo aquilo que, então, poderia ser tomado como tipicamente pornográfico. Antes, pois, de avaliar as declarações revolucionárias, recorro a uma distinção efetuada por Jorge Leite Jr., em seu Das maravilhas e prodígios sexuais, entre a exaltação elitista do erotismo e da negação do pornográfico:

A pornografia encara o sexo considerado ilegal, ilegítimo, perigoso e desestruturador do "estabelecido". O erotismo é a representação da sexualidade limpa, legal e organizada, pois já foi aceita por grupos culturalmente "estabelecidos". Normalmente, o "erótico" nunca é voltado para o prazer em si mesmo como um fim legítimo, mas sempre é usado como um meio para algo maior: o questionamento das relações de poder, o sentimento da paixão, entre algumas possibilidades (LEITE JR., 2006, p.34, grifo meu).

\footnotetext{
${ }^{8}$ A numeração tem fins explicativos, pois serão retomadas a seguir.

${ }^{9}$ Os quatro trechos correspondem à Madonna (1992a).
} 
A separação das discursividades, de acordo com Leite Jr., tem o solo arqueológico fixado a partir do século XVIII, num processo de adensamento da diferenciação cooptado pelo universo da arte. Assim, enquanto a pornografia estaria ligada ao popular, ao inculto e via de regra ao anômalo e bestial, o erotismo tomaria os mesmos objetos, invertendo-os no modelo da transgressão, dando a eles a aura tática de manifestação da resistência. Esse caráter transformador dos discursos sexuais pode ser lido, conforme o autor, desde Sade até Bataille, passando pela fotografia e pela moda do século XX.

Desta perspectiva diferenciadora, o discurso de Madonna ocupa um nicho - o das sexualidades “desviantes" - do pornográfico (em Sex se trata de mostrar aquilo que mais se aproxima do "desviante”), invertendo-o na forma do erotismo - não é à toa que o álbum chama-se Erotica. Estratégico, porque o movimento de assumir o discurso proibido a conforma como portadora da verdade, pois corajosa e transgressora. Estratégico, pois num só golpe garante a verdade de si e legitima a cantora como artista, rompendo com a aura de estrela pop adolescente com parcos recursos musicais. ${ }^{10}$

Isso é justificado, todavia, justamente porque a modificação operada corresponde à vida verdadeira que Madonna. Vamos aos recortes da entrevista: ao questionar as relações de poder sexual estabelecidas, Madonna se coloca como porta-voz da diversidade, desde sexuais até étnicas (2). Só o faz, porém, porque seu discurso é o do artista, cujo inconformismo serviria para garantir a diferença ética perdida (1).

Se, então, é possível que haja obscenidade (3), Madonna inverte a moeda, apontando que a obscenidade sexual é apenas uma espécie de bode expiatório para obliterar a verdade sobre o obsceno, só alcançada pela militância artística: a obscenidade está em não observar o quão invertidos estão nossos conceitos em relação às verdadeiras questões. E, finalmente: tal se deve a um impedimento justamente relativo às operações com a verdade, já que na América as pessoas “não dizem a verdade”(4).

Atentemos: Madonna segue elencando, junto com a ausência da verdade, a ausência da diversão. Divertir-se, então, estabelece a relação entre o rompimento com a ordem da repressão, do interdito ao gozo.

Madonna-Marcuse, a pretensão é deslindar o real e colocá-lo numa ordem de prazer e gozo diversificado. Se, então, é mister escandalizar e subverter a fim de se chegar ao eidos do que existe, tal se dá somente sob a égide de reconstrução de si na praça pública. Madonna se oferece ao "sacrifício" público na medida em que esse confere a ela a posição necessária para cometer a verdade.

\section{Parrêsia cínica?}

Relembro as cinco características que unem vida verdadeira, outro mundo e parrêsia cínica (FOUCAULT, 2009): vida não dissimulada, independente, reta, soberana e escandalosamente alterando o nomos.

\footnotetext{
${ }^{10}$ Há que se fazer - não é tarefa deste trabalho - um apanhado da transformação de Madonna de ícone adolescente e popular para seu consumo como artefato mais elitizado. É surpreendente como, a partir de Sex, suas qualidades começam a ser exaltadas e as críticas mais comuns recobrem cada vez menos as dificuldades técnicas de Madonna como cantora. Tornada bios, parece que essa Madonna já detém, no escopo de sua vida público-privada, as prerrogativas da vida artística.
} 
É certo que Madonna não se apresenta como modelo de vida paupérrima nem bestial, mas algo do que Foucault (2009) evoca como o caráter bestial dos cínicos permanece, sob a forma da humilhação e do desrespeito públicos: as mídias passam a retratar Madonna como louca, como doença social, como pária (TAMBORRELLI, 2003), enquanto ela parece se alimentar dessa publicidade negativa para imputar uma modificação: a vida só pode ser outra quando se é excluído do mundo do mesmo. Permanecer reta em seus princípios e soberana em sua militância confere a ela a modalidade do dizer verdadeiro, justamente porque a implicação entre sua constituição como sujeito é direta em relação a sua estetização midiática da existência.

Entretanto, é preciso rediscutir essa modalidade parresiástica.

\subsection{Madonna, essa simulação}

Numa segunda entrevista dada no lançamento de Sex, ao ser inquirida sobre supostas restrições da sua gravadora ao conteúdo do livro, Madonna responde que as únicas censuras seriam sobre fotos de pedofilia e zoofilia, o que não a incomodariam porque seu interessa não passava por esses estratagemas (MADONNA, 1992b).

O conteúdo de Sex, então, precisa ser repensado como modo de transgressão. Primeiramente, porque Madonna não ultrapassa o limite estabelecido pela indústria que a precede e circunscreve ou, mais diretamente, porque fala o que pode e o que deve dizer, ainda que pareça freneticamente militante. Destarte, quando não discute o veto da Warner aos desvios mais ligados ao hardcore e ao pornográfico, o que seu discurso promove é um agenciamento da forma erotizante, com pretensões estéticas.

Depois, porque Sex instiga uma espécie de manutenção de relações dentro da ordem do dispositivo sexual. A primeira página de texto se inicia com um chamado acerca do uso da camisinha: "Fantasies take place in a perfect world. A place without aids. Unfortunately, the world is not perfect and I know that condoms are not only necessary but mandatory” (MADONNA, 2009, p.4).

Não se tratará, nesse discurso, de ampliar o espectro do desejo desvirtuando a ordem da saúde e do bem-estar social. A amplitude da revolução é a do bom tom das fotografias de moda que seguem por todo o livro. Não nos enganemos, pois o discurso de Madonna é prenhe na assunção do fake, do simulacro.

Finalmente, Sex recorre a uma transparência radical, um tudo dizer do sexo e um tudo dizer de si mesmo. Tal condição, como já foi dito, poderia recorrer a uma explicação parresiástica: Madonna estetiza sua existência e expõe-se a fim de repensar o dispositivo e oferecer uma alternativa crítica diante do posto. O que a tornaria cinicamente parresiástica seria essa instanciação entre verdade, verdade de si e bios.

Todavia, assim como a releitura de breves trechos nos aponta a dimensão disciplinada de sua transgressão - o que, certamente, não corresponde à vida/alteridade dos cínicos-, essa disciplina acaba por fazer proliferar o discurso da sexualidade, nos moldes previstos por Foucault: o dispositivo como o próprio funcionamento do desejo pelo poder. 
Isso posto, ainda resta uma outra dimensão dessa impossibilidade. Neste caso, é preciso pensar, com Baudrillard (1991), na condição esvaziada dos discursos sexuais. Contrafoucauldianamente, Baudrillard faz ver o quão enfraquecido é o poder do dispositivo ou: o discurso sobre o poder, o sujeito e o sexual só pode aparecer na forma da teoria quando perde sua eficácia nas práticas - algo que já havia sido dito, sobre o poder, no Esquecer Foucault.

O interesse aqui, porém, é relativo ao poder ainda existente no simulacro do poder, no simulacro de sexo que o discurso de Madonna esgota: só se é parresiasta na configuração da cantora justamente pela ineficácia de um discurso de produção e manutenção do poder, cujo objeto é apenas uma visibilidade empobrecida. Nos termos de Baudrillard (1991), há então uma cisão entre os saberes do gozo, do sexo e da transparência pornográfica e aquilo que ele denomina de sedução, que pode ser aduzido como o lado-de-fora dessa ordem natural do desejo, a saber, um uso fora-da-Lei dos saberes sobre o corpo, ritualizado em uma forma que não a da produção do prazer via gozo. Assim, quando o sexo e a pornografia ascendem como questão, tal é sinal de uma cultura que obedece à ordem da produção e da permanência:

Somos a cultura da ejaculação precoce. Cada vez mais, qualquer sedução, qualquer forma de sedução, que é um processo altamente ritualizado, apaga-se por trás do imperativo sexual naturalizado, por trás da realização imediata e imperativa do desejo. Nosso centro de gravidade deslocou-se de uma economia libidinal que só deixa lugar à uma naturalização do desejo destinado à pulsão e ao funcionamento maquínico, mas sobretudo ao imaginário do recalque e da liberação (BAUDRILLARD, 1991, p.47)

Baudrillard (1991) vincula o poder da sedução ao feminino e questiona o conceito de dominação falocêntrica, discutindo se não foi um modelo fora do gozo, pelo qual as mulheres se constituíram na suposta austeridade pré-feminista, o responsável pela manutenção da sedução como elemento fora da disciplina. Então: aquilo que era restrição e negativo, quem sabe não se tornara uma prerrogativa de novos modos de relacionar-se consigo e com o outro?

Partindo dessa cisão, novamente o discurso de Madonna: configurar uma estética da existência que transcende os limites do artístico não garantiria parrêsia, sequer a da modalidade cínica. O discurso aqui não opera com a transgressão e o risco, mas inaugura uma forma simulada destes últimos: ofereço a existência à publicidade produzindo e reproduzindo a ordem e a disciplina do dispositivo. Comportamento tático e estratégia do escândalo, justamente na incapacidade de se fazer escandaloso, eis o discurso oferecido por essa modalidade pop de parrêsia.

Que, contudo, tem a força da produção e reconfigura o modo de ser da discursividade pop: depois de Madonna, há um estreitamento entre a condição de militância via vida verdadeira e a legitimidade enquanto vida artística. Não se trata, porém, de parrêsia: expulsou-se a preocupação de verdade e se permaneceu apenas com os exercícios da maquinação e da espetacularização, na ordem recorrente do simulacro. 


\section{CONSIDERAÇÕES FINAIS}

Neste texto, pretendi discutir o discurso de Madonna segundo seu relacionamento possível com a noção de parrêsia cínica. A tentativa era observar como os mecanismos dessa modalidade de dizer o verdadeiro permaneciam operantes e como auxiliavam na transformação pela qual teria passado o modelo de artista pop - eis a hipótese de trabalho.

Como tentei mostrar, ainda que Madonna permaneça agregada ao vértice existência verdadeira - discurso verdadeiro, seu discurso evoca a ausência de possibilidade de distinção ética, o que faz pensar numa má parrêsia, empenhada com uma bajulação, desta feita não mais às figuras de mando mas às figuras exteriores a este. Assim é que seu discurso reverbera de forma permanente na massa daqueles que se identificam como ousiders do desejo e que são responsáveis pela manutenção de sua importância pública.

Ao analisar brevemente o discurso de Madonna, então, fundamental é pensá-lo como simulacro de parrêsia, já que não implica nem uma transformação e um cuidado de si que incorra risco, nem um dizer verdadeiro que exija coragem efetiva. Tudo se passa numa pop-bajulação. Num simulacro que, desrealizado e virtualizado, faz as vezes do real com mais capacidade de produção do que qualquer real perdido.

\section{REFERÊNCIAS}

ADORNO, F. P. A tarefa do intelectual: o modelo socrático. In: GROS, F. (Org.). Foucault: a coragem da verdade. 2. ed. São Paulo: Parábola, 2004. p. 39-62.

ANDERSEN, C. Madonna: uma biografia não-autorizada. Rio de Janeiro: Record, 1991.

BAUDRILLARD, J. Da sedução. Campinas, SP: Papirus, 1991.

DELEUZE, G. Foucault. São Paulo: Brasiliense, 2005.

FOUCAULT, M. Le courage de la verité: le gouvernement de soi e des autres II, Cours au Collège de France, 1984. Paris: Gallimard, Seuil, 2009.

FOUCAULT, M. A hermenêutica do sujeito. 2. ed. São Paulo: Martins Fontes, 2006.

GAGA, L. Lady Gaga não é uma personagem. Rolling Stone, São Paulo, n.33, jun. 2009, p. 68. Entrevista concedida a Austin Scaggs.

GROS, F. A parrhesia em Foucault (1982-1984). In: GROS, F. (Org.) Foucault: a coragem da verdade. 2. ed. São Paulo: Parábola, 2004. p.155-166.

LEITE JUNIOR, J. Das maravilhas e prodígios sexuais: a pornografia "bizarra” como entretenimento. São Paulo: Annablume, 2006. 
MADONNA, L. V. C. Sex, 2009. Disponível em: $<$ http://rapidshare.com/files/ 129907908/Madonna___Sex__Full_Book___ainsubmissa.blogspot.com.pdf $>$. Acesso em: 22 jul. 2009.

MADONNA. Ela é assim e nunca pede desculpas. Veja, São Paulo, 25 nov. 1992a. Entrevista concedida a Elio Gaspari.

Disponível em: <http://veja.abril.com.br/idade/estacao/madonna/1992.html>. Acesso em: 22 jul. 2009.

MADONNA. Entrevista concedida à MTV Britânica, 1992b. Disponível em: <http://www.madonnaonline.com.br/entrevistas/92_03.asp>. Acesso em: 22 jul. 2009.

SANTOS, F. El riesgo de pensar. In: ABRAHAM, T. El último Foucault. Buenos Aires: Sudameicana, 2003. p. 40-107.

TARABORRELLI, J. R. Uma biografia íntima: Madonna. São Paulo: Globo, 2003. 